University of Nebraska - Lincoln

DigitalCommons@University of Nebraska - Lincoln

Faculty Publications - Department of

Philosophy

Philosophy, Department of

Spring 1972

\title{
The Social and the Causal Concepts of Responsibility
}

Nelson T. Potter Jr.

University of Nebraska - Lincoln, kjohnson6@unl.edu

Follow this and additional works at: https://digitalcommons.unl.edu/philosfacpub

Part of the Continental Philosophy Commons, and the Ethics and Political Philosophy Commons

Potter, Nelson T. Jr., "The Social and the Causal Concepts of Responsibility" (1972). Faculty Publications Department of Philosophy. 11.

https://digitalcommons.unl.edu/philosfacpub/11

This Article is brought to you for free and open access by the Philosophy, Department of at DigitalCommons@University of Nebraska - Lincoln. It has been accepted for inclusion in Faculty Publications Department of Philosophy by an authorized administrator of DigitalCommons@University of Nebraska - Lincoln. 


\section{The Social and the Causal Concepts of Responsibility \\ Nelson Potter, Jr. \\ University of Nebraska-Lincoln}

In a recent article in this journal Professor William L. Blizek argued that there is a distinction between a social and a causal concept of "responsibility," and that understanding this can help us understand the concepts of legal, societal, and moral responsibility. ${ }^{1}$

He says that in cases like " $\mathrm{X}$ was responsible for the automobile accident," the concept of responsibility is causal, not social. He also mentions the example, "Faulty wiring was responsible for the fire," an example that makes it clear that sometimes "responsibility" has an entirely causal meaning, "and may be equivalent to 'causality.'" 2

But he adds: "Other uses of 'responsibility,' however, suggest a concept which is incompatible with the causal concept-a social concept of responsibility."' 3 He gives as an example " $\mathrm{X}$ is responsible for the decorations at the forthcoming gala ball." This statement, he says, cannot be translated into a causal statement without changing its meaning. He points out that one may choose to accept or not accept responsibility for the decorations, but one cannot choose to accept or not accept responsibility for an accident in the same way. Further, we may, in taking on a responsibility sometimes "engage ourselves to take on a vast, and antecedently unspecifiable range of specific responsibilities," ${ }^{\prime 4}$ and this fact seems to show that the meaning of responsibility here is different from simple causal responsibility. He also points out that the social concept of responsibility allows for

\footnotetext{
${ }^{1}$ William L. Blizek, “The Social Concept of Responsibility," Southern Journal of Philosophy, Volume 9, No.2 (Summer, 1971), pp. 107-111. All further references are to this article.

2 p. 107

${ }^{3}$ p. 107
}

imputation of responsibility for possible rather than actual consequence-as, for example, when we impute the possible consequences of an unsuccessful assassination attempt, or a careless and dangerous but, in tenns of actual consequences, harmless firing of one's rifle. In contrast, when the intended consequences are good (e.g., having a well-decorated gala ball), imputation is for the actual bad consequences (as when the decorations are badly done).

The causal and the social concepts of responsibility share the notions of (a) a causal agent, and (b) some effect for which the agent is a cause. But Professor Blizek argues that the social concept has an additional element not shared by the causal concept: that of an adjudicator, someone who imputes responsibility. ${ }^{5}$ Thus he writes, "social responsibility is not a relationship between cause and effect, but a relationship between an agent and some consequence, as prescribed by an adjudicator." ${ }^{6} \mathrm{He}$ points out that our judgments of the different kind of social responsibility may change, as the society changes; redefinition of social responsibilities by a society is thus both a reflection of social change and a mechanism by which it may take place.

Nelson Potter, Jr. received a B.A. degreefrom Monmouth College (Illinois) in 1961, and a Ph.D. degree from Johns Hopkins University in 1969. He has taught at the University of Nebraska-Lincoln since 1965, and is presently an Assistant Professor there. He has special interests in ethics, aesthetics, and the philosophy of Kant.

${ }^{4}$ p. 108. Blizek is quoting Herbert Fingarette, "Responsibility" (Mind, No. 297, (January, 1966), pp. 58-74), p. 72.

${ }^{5}$ p. 109.

${ }^{6}$ p. 110. 
There is little to dispute in Professor Blizek's account of the role of the adjudicator in affixing the social concept of responsibility. But the claim that there is a different concept of causal responsibility which does not involve any "adjudicator" is one that Professor Blizek has not justified. In the remainder of this essay I wish to show that the causal concept of responsibility requires an "adjudicator" as much as does the social concept, and that the social concept of responsibility can be analyzed into causal terms for the examples that Professor Blizek mentions. I shall not be attempting to show that his account of the social concept of responsibility is incorrect; I shall only show that he has not supported his claim that there are two distinct conceptions of responsibility, one causal and the other social.

Consider " $\mathrm{X}$ was responsible for the automobile accident." We may flesh out this example by supposing that $\mathrm{X}$ went through a red light one foggy morning thereby crashing into $Y$. Was $X$ then the cause of the accident? We may suppose that if $X$ hadn't gone through the red light, the accident would not have occurred. But if $Y$ had not gone through the green light, the accident also would not have occurred. Or if $Y^{\prime}$ s light had also been red, or perhaps if it had not been foggy, or if $X$ had not had an appointment, or if a policeman had been directing traffic, or if $\mathrm{V}^{\prime}$ s car had failed to start that morning, the accident would not have occurred. Thus the accident can be said to have been caused by $X, Y, Y^{\prime}$ s green light, $X^{\prime}$ s appointment, the fog, the fact that V's car started, and the absence of a policeman. How do we decide, from among the items on this list, which we will finally, call "the cause"? An adjudicator of some kind determines which of the causes it is most useful, or interesting, or enlightening to call "the cause."

This same account works for "Faulty wiring was responsible for (or was the cause of

${ }^{7}$ See note 4 . cause of) the fire." We may suppose that if it had not been for the presence of faulty wiring a fire would not have occurred. But the fire also would not have occurred but for the presence of combustible material, oxygen in the atmosphere, electric current passing through the wires, the absence of an afternoon shower, the absence of a fireman within five feet of the wiring when it heated up, and the earlier inability of the owner to pay for rewiring. It is not very interesting or enlightening or useful to say that the fire was caused by the presence of oxygen in the air, or the absence of a fireman, or the poverty of the owner. But such statements may be nonetheless true; and it is again an "adjudicator" who determines that faulty wiring was "the cause" of the fire. Now let us consider " $X$ is responsible for the decorations at the forthcoming gala ball." I think this may be read as " $X$ has promised that he will be the cause of good or adequate decorations for that ball," if $X$ took on the responsibility by making a promise. The reason one can choose to take on this responsibility in a way that one cannot choose with respect to one's responsibility for an auto accident, is that one can choose to be or not be the cause of future, possible states of affairs, whereas one cannot choose to be or not be the cause of either an accident or a past event. When one promises to be the cause of something, he is often engaging himself "to take on a vast, and antecedently unspecifiable range ofspecific responsibilities." 7 For when one promises to complete a task, one promises to be the causally sufficient condition of its completion, and the causally sufficient conditions of events are usually "vast and unspecifiable." Thus the presence of vast and unspecifiable ranges of responsibilities does not point toward any non-causal conception of responsibility, but only toward the concept of causally sufficient conditions. The fact that $X$ has promised to be the cause of good or adequate decorations means he is responsible if the decorations are bad, 
since he has then failed to keep his promise. Cases where one is in some sense responsible for merely possible consequences can be analyzed in terms of contrary-to-fact conditionals. For our examples we get:

If the assassin had succeeded, his action would have caused the death of a President.

If someone had been in the path of the bullet, $X^{\prime}$ s firing would have caused his injury or death.

But these are like:

If the wolf had succeeded, his action would have caused the death of the elk.

If someone had been in the tornado's path, he would have been injured or killed.

We make judgments about possible or intended consequences, regardless of whether there is any "social concept of responsibility" involved in the judgment or not. This is because we can learn from such judgments about how to avoid certain kinds of bad consequences. So the reference to possible consequences is not a mark of a social as opposed to a causal concept of responsibility; it is simply a mark of our general interest in avoiding certain kinds of bad causal consequences.

Professor Blizek's paper correctly points out the role of the "adjudicator" in making judgments of responsibility. But I have argued that the adjudicator's role extends to certain kinds of purely causal assignments of responsibility, especially those which seek to discover "the cause" of an occurrence. Some philosophers think that the "causal concept of responsibility" is the concept of a kind of responsibility that is "objective" and non-relative, while the social concept of responsibility is adjudicatordependent' perhaps in some way arbitrary, and relative to human interests and purposes. In fact, the social and causal concepts of responsibilityare equally adjudicator-dependent, equally "objective," and equally relative to human interests and purposes. 